\title{
Traditional Medicinal Vegetables in Northern Uganda: An Ethnobotanical Survey
}

\author{
Rebecca Nakaziba $\mathbb{D}^{1,2}$ Maxson Kenneth Anyolitho $\mathbb{D}^{1},{ }^{1}$ Sharon Bright Amanya $\mathbb{D}^{1}{ }^{1}$ \\ Crispin Duncan Sesaazi $\mathbb{D}^{2}{ }^{2}$ Frederick Byarugaba $\mathbb{D}^{3},{ }^{3}$ Jasper Ogwal-Okeng $\mathbb{D}^{1}$, \\ and Paul E. Alele $\mathbb{i D}^{2}$ \\ ${ }^{1}$ Faculty of Health Sciences, Lira University, Lira, Uganda \\ ${ }^{2}$ Department of Pharmacology and Therapeutics, Mbarara University of Science and Technology, Mbarara, Uganda \\ ${ }^{3}$ Department of Microbiology, Mbarara University of Science and Technology, Mbarara, Uganda \\ Correspondence should be addressed to Rebecca Nakaziba; d2rebecca1@gmail.com
}

Received 25 January 2021; Revised 1 June 2021; Accepted 22 June 2021; Published 15 July 2021

Academic Editor: Severino Matias de Alencar

Copyright (c) 2021 Rebecca Nakaziba et al. This is an open access article distributed under the Creative Commons Attribution License, which permits unrestricted use, distribution, and reproduction in any medium, provided the original work is properly cited.

\begin{abstract}
Background. A wide range of indigenous vegetables grow in Uganda especially during rainy seasons but scarcely during droughts, except those that are commercially grown. Although a number of these vegetables have medicinal values, they have not been satisfactorily studied besides conservation. Therefore, we conducted a cross-sectional ethnobotanical survey in Northern Uganda in order to document traditional medicinal vegetables and their uses. Methods. Qualitative and quantitative approaches of data collection and analysis were employed using semistructured, interviewer-administered questionnaires as well as key informant interviews following international ethical codes. Fidelity levels and informant consensus factors were also calculated. Results. 13 traditional vegetables belonging to 10 families were reported to serve as folk medicines. The most dominant families were Fabaceae $(23.08 \%)$ and Solanaceae $(15.38 \%)$. The most often used vegetables were Corchorus spp., Hibiscus spp., and Asystasiagangeticafor musculoskeletal (51\%), gastrointestinal (34.3\%), and malaria (31.8\%). The vegetables were cultivated in the backyard and the leaves stewed for the different ailments. The informant consensus factor was the highest for Corchorus spp., in the treatment of joint pain/stiffness (0.92-1) while the highest fidelity level was (60.42\%) for Amaranthus spp., in the management of anemia. Conclusions. Northern Uganda has numerous traditional vegetables with medicinal benefits. Diseases treated range from gastrointestinal to reproductive through musculoskeletal abnormalities. The community obtains vegetable leaves from the backyard and stews them regularly for the medicinal purposes with no specific dosage. Therefore, we recommend studies to verify in laboratory models the efficacy of these vegetables and standardize the dosages.
\end{abstract}

\section{Introduction}

Despite the aggressive rivalry from conventional medicines, natural products have remained drugs of choice for some individuals due to their safety and efficacy [1]. Individuals prefer to use traditional medicines because of affordability and accessibility as well as desire for personalized health care coupled to fear for adverse events associated with synthetic drugs [2, 3]. Usage also surges when conventional medicines are ineffective in the treatment of diseases such as cancer and in the face of new infectious diseases $[4,5]$. Traditional medicines of plant origin are used by about $80 \%$ of persons in the developed countries $[6,7]$ while more than $30 \%$ of the modern pharmacological drugs have their origin directly or indirectly linked to plants $[8,9]$. An estimated $25 \%$ of the drugs prescribed worldwide are derived from plants [10] and out of the total 252 drugs in the World Health Organization's (WHO) essential medicine list, $11 \%$ are utterly of plant origin $[1,11]$. Moreover, $80 \%$ of 122 plant derived drugs have their uses related to their original ethnopharmacological purposes [12]. 
Traditional leafy vegetables worldwide are a valuable and cheap source of nutrition for a balanced diet [13]. In addition, these vegetables serve as folk medicines [13] for treating conditions such as toothache (Amaranthus viridis. L.), acute abdominal pain (Celosia argentia L.), painful urination (Portulacaoleracea L.), headache (SmithiasensitivaAit.) and diarrhea (C. mimosoides L.) [13] rheumatism and cough (Marsileaminuta Linn), and helminthes infestation (Spinaciaoleracea Linn.) [14].

In Uganda, traditional vegetables are plant species which are either native or were introduced into the country a while ago and are presently being cultivated and their leaves used as a sauce to the staple foods $[15,16]$. Diverse species grow in all the geographical regions of the country. However, their level of cultivation and consumption differs depending on the local customs, beliefs, practices, and staple foods of the folk as well as soil/climate types [15]. Some of these traditional vegetables have been domesticated, whereas others grow and are gathered as wild or semiwild flora $[15,16]$. Domesticated vegetables are planted in home-based gardens (backyards) with trivial devotion in their production. The production of traditional vegetables is suitable for several families as they grow within a short time period shortly after the start of rains subsequent to dry seasons [15]. Further, traditional vegetables are a major source of ascorbic acid and various micronutrients in the diet $[16,17]$ in Uganda. The vegetables contain vitamins $(\mathrm{A}, \mathrm{B}$, and $\mathrm{C})$ and proteins and minerals such as iron, calcium, phosphorus, iodine, and fluorine in varying amounts but adequate for normal growth and health [17]. According to the FAO Food Balance Sheet for Uganda, traditional food plants supply about $90 \%$ energy, $76 \%$ protein and $63 \%$ fat, and most of vitamins $\mathrm{A}$ and $\mathrm{C}$, iron, and dietary fiber [15]. These food values are vital necessities for normal growth and defense against protein/calorie malnutrition in humans [15]. Traditional vegetables ensure a well-balanced diet in rural areas [13]. In some cases, parts of traditional vegetable species serve as staple foods such as the mature fruits of $C$. maxima and the tubers of $C$. benghalensis, Ipomoea spp., M. esculenta, and S. edule.

Not only are these traditional vegetables a source of food, they are as well used for medicinal purposes. For example, prevention of blindness especially in children using vitamin A found in all dark green leafy traditional vegetables such as Amaranthus (dodo), Solanumaethiopicum (Nakati), Manihotesculenta (cassava leaves), and Ipomeabatatas (sweet potato leaves). On the other hand, vegetables like Solanumindicum subsp. distichum (Katunkuma) are believed to control high blood pressure [17]. In addition, the leaves of B. pilosa are used for wounds and boils; while the juice, for various eye and ear problems; and a decoction for rheumatism, stomach disorders, and intestinal worms; yet the roots, for malaria treatment. Other important medicinal traditional vegetables include C. obtusifolia, Celosia argentea, C. benghalensis, Corchorus spp., G. abyssinica, Hibiscus spp., L. siceraria, L. cylindrica, S. indicum, S. indicum subsp. distichum, T. indica, and Tribulus spp. [15]. According to a study carried out at Mwana Mugimu nutrition services, traditional vegetables were identified as a critical nutritional resource (especially in children) [18]. The study suggested that families should make nutritious foods for young babies using locally available foods, including traditional vegetables in the fight against malnutrition [15]. Traditional vegetables are also used to obtain various other products such as ornaments, dyes, tobacco and coffee substitutes, pipes, ropes, sacks, mats, containers, ladles, industrial oils including drug sponges, carriers, soil fertilizers, and livestock feeds [15].

Whereas these traditional vegetables are easily accessible to the communities and would conveniently and cheaply be used in management of various disease conditions, studies regarding their medicinal uses are scanty in the country. Besides, there is poor and inadequate documentation of the traditional medicinal uses of most of these plants since it is often privately and verbally passed on from one generation to another. This leads to high risk of loss of information about these plants including their medicinal values [19, 20].Therefore, in this study, we set out to document the traditional vegetables with their medicinal uses in Northern Uganda through an ethnobotanical survey.

\section{Methods}

2.1. Study Site and Setting. Data was collected from the Lango subregion, Northern Uganda. Northern Uganda as a region is divided into 5 subregions: Acholi, Karamoja, Lango, West Nile, and Teso. There are several ethnic groups in the region such as Acholi, Langi, and Ateso tribes. The region has a hot climate, and the natives are subsistence farmers. They mostly grow maize, soya beans, simsim, cassava, millet, ground nuts, and beans. The residents typically eat starchy foods that frequently accompanied by pasted green leafy vegetables of different kinds. They are fond of using plants including vegetables as traditional medicines for disease treatment. For instance, they use Hibiscus spp for the treatment of cough and the roots Cleome gynandra to facilitate birthing. The northern region of Uganda has 30 districts with a total population of $7,188,139$ and a total area of $85,391.7 \mathrm{~km}^{2}$ [21] (Figure 1).

2.2. Study Design and Sampling. A descriptive mixed method employing both quantitative and qualitative approaches of data collection and analysis was used to describe the traditional medicinal vegetables in Northern Uganda in an ethnobotanical survey $[22,23]$. This was done to enable comprehensive data collection. A multistage simple random sampling technique [24] was used to select the units (i.e., subregion, district, subcounties, parishes, and villages) for quantitative data in order to properly portray the study area and be able to generalize the study outcomes. The sample units were selected by listing the names of all units (at each stage) on small pieces of paper which were mixed up. A piece was picked, its name noted down in a book and replaced in the pool. The process was repeated until all the units were identified. One subregion, one district, four subcounties, 2 parishes per subcounty and 6 villages from each parish, and finally 5 households per village were selected. The study participants were selected based on the convenience sampling technique [24] for easy access. A sample size of 246 households (one person per household) was determined following 


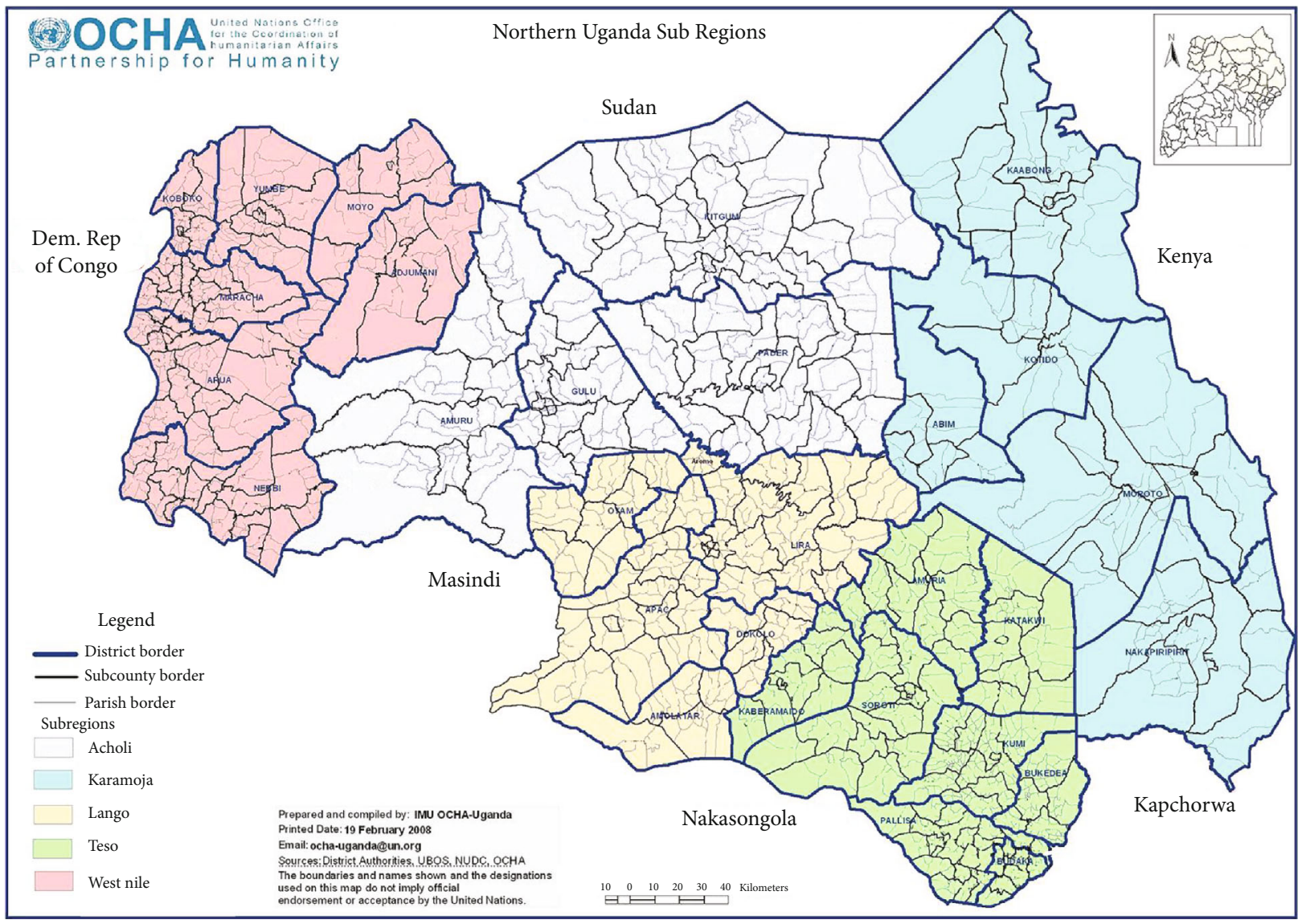

Figure 1: Map of Northern Uganda.

a formula by methodology [25]. However, two [2] of the questionnaires were invalid leaving a total of 244 which are reported in this paper. Of these, five herbalists were selected using purposive and snowball techniques [24] for qualitative data.

2.3. Ethnobotanical Data Collection. Quantitative and qualitative data was collected using a semistructured, intervieweradministered, questionnaires [26, 27] and key informant interviews [28], respectively. Interviews were conducted in the local language (Luo) using research assistants who were skilled undergraduates from the region [26]. The data collection tool was designed to obtain details regarding the subcounty, parish, and village name; participant biodata; commonly consumed vegetables (local names); vegetables with medicinal benefits; their therapeutic uses; plant part used; style of preparation; route of administration; and quantity used [27]. In addition, the participants were requested to mention the medicinal vegetables they most commonly used, the most effective (in their opinion), and the source of information regarding the medicinal value. This information was carefully recorded in the tool during the interviews. The data collection tool was pretested before use [29] to ensure content validity, and the questionnaires were properly checked for completeness and correctness before leaving the field following data collection. A total of 246 persons were interviewed but during analysis, two were invalid. Therefore, 244 are reported in this paper.
Of these, 239 (165 female and 74 male) were community members while 5 ( 1 female and 4 males) were known herbalists (key informants). The herbalists were individually interviewed following a key informant interview guide generated for the study [28]. The study participants were natives aged 45 years and above except for the key informants whose age was not regarded. Before conducting the interviews, the local area leaders were contacted to obtain permission for the study, and informed consent was obtained from each participant. In addition, international ethical codes of conduct were ensured throughout the study [30]. Further, the study was approved by Research and Ethics Committee (REC${ }_{1 / 7}$ ) of Mbarara University of Science and Technology as well as the Uganda National Council for Science and Technology (UNCST-HS2589). The scientific names were obtained from previous studies in the study location $[15,31]$ with some of the samples identified by a botanist at Makerere University, Botany Department.

2.4. Data Analysis. The quantitative study responses obtained from the survey were coded and double entered into SPSS v.20 for a descriptive statistical analysis of frequencies and percentages. This was done in order to assess the significance of the vegetables in the study area. The information was summarized and reported in the form of figures and tables. Further, the informant consensus factor (ICF) was calculated to describe the effectiveness of the vegetable for each disease 
$[32,33]$ using the formula: $\operatorname{ICF}=(n-n t) /(n-1)$, where $n$ is the number of individual reports of a plant use for a particular illness while nt is the total number of species used by all informants for this illness. Furthermore, the fidelity level FL for the 10 commonly used vegetables for medicinal benefits was calculated as follows: $\mathrm{FL}=\left(I_{p} / I_{u}\right) \times 100 \%$, where $I_{p}$ is the number of informants who suggested the use of a species for the same major use (therapeutic), and $I_{u}$ is the total number of informants who mentioned the plant species for any use [33]. There was no major difference between the reports of the key informants and the general community. Therefore, the information obtained from the key informants was incorporated in that of the general community and reported as a whole.

\section{Results}

3.1. Participant Sociodemographics. A total of 244 participants' responses were valid in the current study. 239 were community members while 5 were herbalists. Majority (59.8\%) were aged $45-49$; 68\% were females; $96.3 \%$ belonged to the Lango tribe; $56.9 \%$ were Roman Catholics; $51.6 \%$ had primary level education; while $91.4 \%$ were subsistance farmers [Table 1].

3.2. Traditional Medicinal Vegetables and Their Uses in Northern Uganda. 13traditional vegetables, namely, Hibiscus spp, Cleome gynandra, Corchorus spp, Crotalaria ochroleuca, Vigna unguiculata, Brassica oleracea, Cucurbita maxima D, Amaranthus spp., Capsicum spp., Solarium nigrum L., Acalypha bipartite M., Cassia obtusifolia L., and Crassocephalumrubens, were reported as folk medicines. They belonged to 10 families including Malvaceae (7.69\%), Cleomaceae(7.69\%), Tiliaceae (7.69\%), Fabaceae (23.08\%), Brassicaceae (7.69\%), Cucurbitaceae (7.69\%), Amaranthoideae (7.69\%), Solanaceae (15.38\%), Euphorbiaceae (7.67\%), and Asteraceae (7.69\%) [Table 2].

3.3. Vegetables Most Often Used for Traditional Medicinal Purposes. Out of the 13 vegetables used for medicinal purposes in the region, the most often used as reported by the participants were Corchorus spp (24\%), Hibiscus spp (17\%), and Crotalaria ochroleuca (16\%) (Figure 2).

3.4. Most Effective Medicinal Vegetables. Reports on the most effective medicinal vegetable by the study participants indicated Corchorus spp (Figure 3).

3.5. Plant Part Used and Method of Preparation. For all of the medicinal vegetables, the leaves (>95\%) were stewed (>98\%). The leaves and/or young shoots are harvested, chopped into small pieces, and boiled. Groundnuts/simsim paste often added. Sometimes, the paste is not added. This is done to improve effectiveness of the vegetable in the disease condition being treated. In most cases, the sauce is eaten as a whole. In some of the conditions, only the soup is drunk. In a few instances, however, raw leaves were chewed, for example, Acalypha bipartite $M$ and Crotalaria ochroleuca in the treatment of tooth decay $(0.8 \%)$ and malaria respectively. The roots plus the stem of Cleome gynandra were also crushed raw and the juice obtained used in prolonged labor
TABle 1: Participants' sociodemographic profile.

\begin{tabular}{|c|c|c|c|}
\hline Variable & Description & Frequency & Percentage \\
\hline \multirow{4}{*}{ Age } & $45-49$ years & 146 & 59.8 \\
\hline & 50-54 years & 38 & 15.6 \\
\hline & 55-59 years & 18 & 7.4 \\
\hline & 60 and above & 42 & 17.2 \\
\hline \multirow{2}{*}{ Gender } & Female & 166 & 68.0 \\
\hline & Male & 78 & 32.0 \\
\hline \multirow{4}{*}{ Tribe } & Lango & 235 & 96.3 \\
\hline & Acholi & 6 & 2.5 \\
\hline & Alur & 1 & 0.4 \\
\hline & Bantu & 2 & 0.8 \\
\hline \multirow{5}{*}{ Religious affiliation } & Anglican & 77 & 31.8 \\
\hline & Roman Catholic & 139 & 56.9 \\
\hline & Moslem & 2 & 0.8 \\
\hline & Pentecostal & 25 & 10.5 \\
\hline & Other & 1 & 0.4 \\
\hline \multirow{4}{*}{ Education level } & Informal & 77 & 31.6 \\
\hline & Primary & 128 & 52.5 \\
\hline & Secondary & 35 & 14.3 \\
\hline & Other & 4 & 1.6 \\
\hline \multirow{4}{*}{ Source of income } & Subsistence farming & 223 & 91.4 \\
\hline & Business & 12 & 5.0 \\
\hline & Formal employment & 6 & 2.5 \\
\hline & Other & 3 & 1.2 \\
\hline
\end{tabular}

and placental expulsion (3.4\%). In addition, the leaves of Hibiscus spp. were heated and placed on the wounds for healing purposes $(0.4 \%)$.

3.6. Mode of Administration. The most applied route of administration was oral (99\%). For eye/ear infections as well as toothaches, administration was topical (Table 2).

3.7. Cultivation of Medicinal Vegetables in Northern Uganda. Most of the medicinal vegetables in the current study were cultivated in the backyard (Figure 4).

3.8. Informant Consensus Factor (ICF). Using the reports of the study participants, the ICF for the 8 most commonly used traditional medicinal vegetable was calculated in order to highlight species that have healing potential for specific major purposes based on the homogeneity of informant's knowledge. The highest ICF value was 1 for Corchorus spp. (joint stiffness), Hibiscus spp. (poor lactation), and Brassica oleracea(cancer) (Table 3 ). Values close to 1 indicate a high rate of informant agreement on a plant.

3.9. Fidelity Level (FL). The FL for the traditional medicinal vegetables which treated diseases with ICF values 0.5 and above was also calculated. According to the findings, the highest fidelity level value was $60.42 \%$ (Table 4 ). 


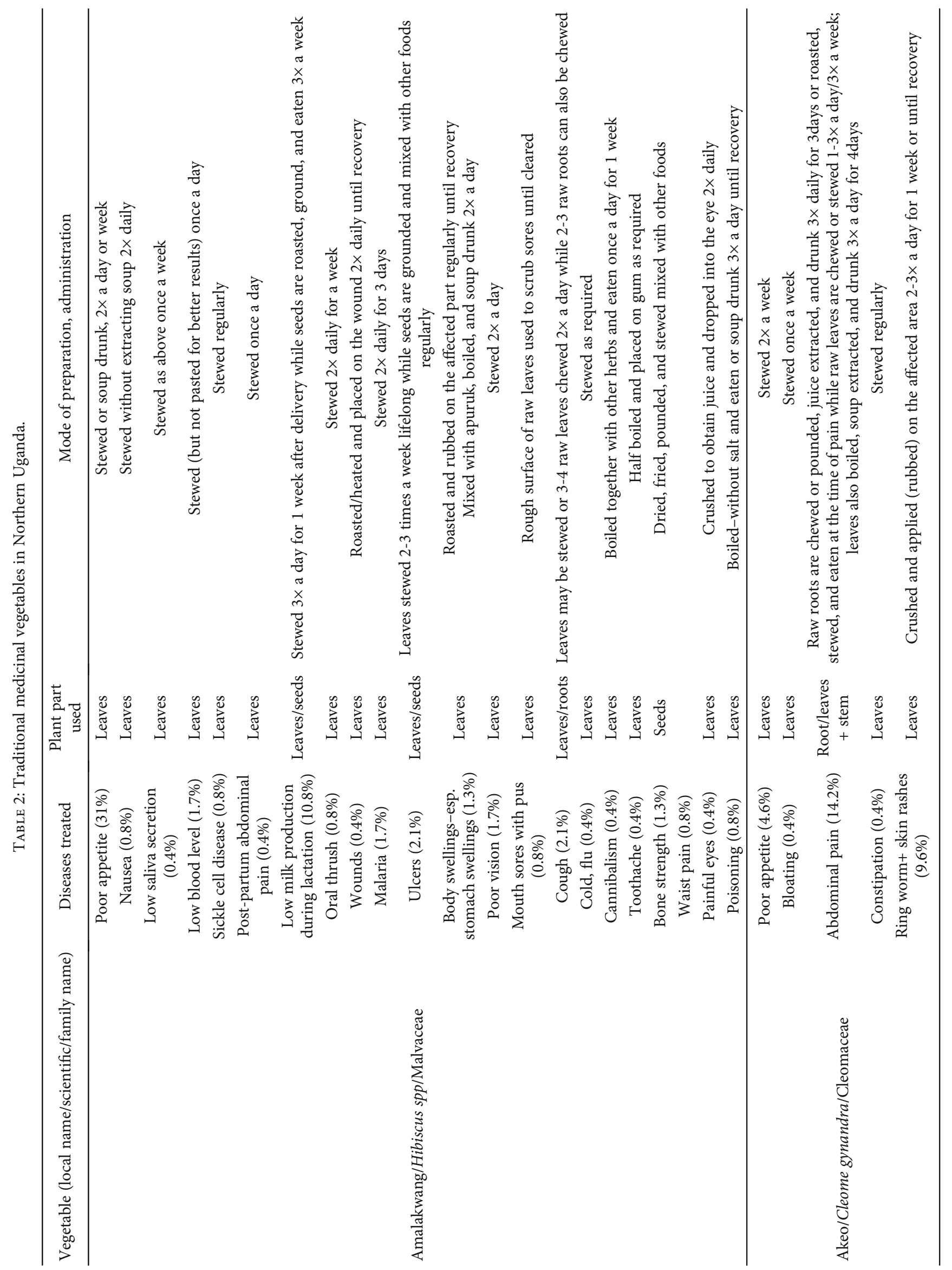




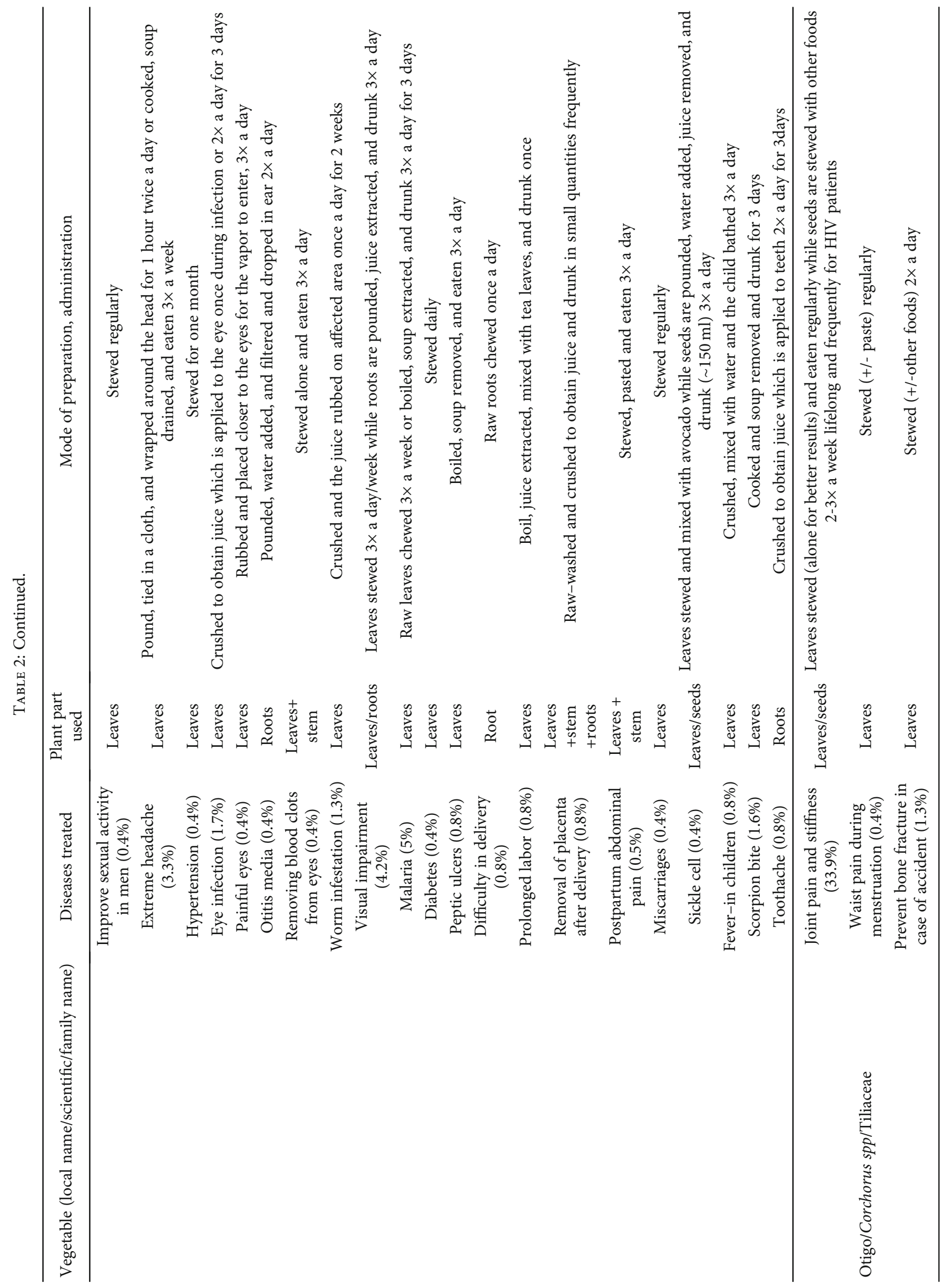




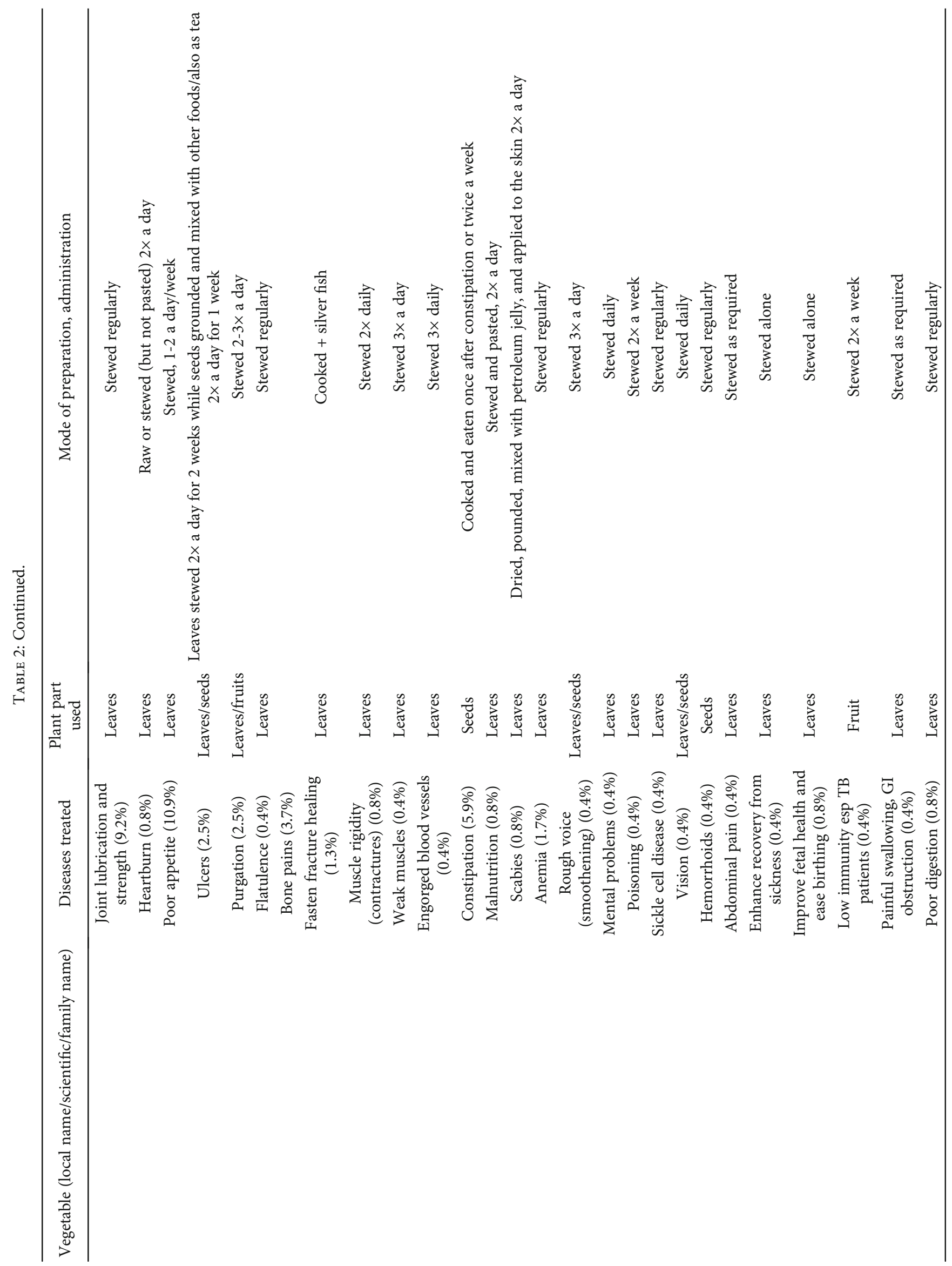




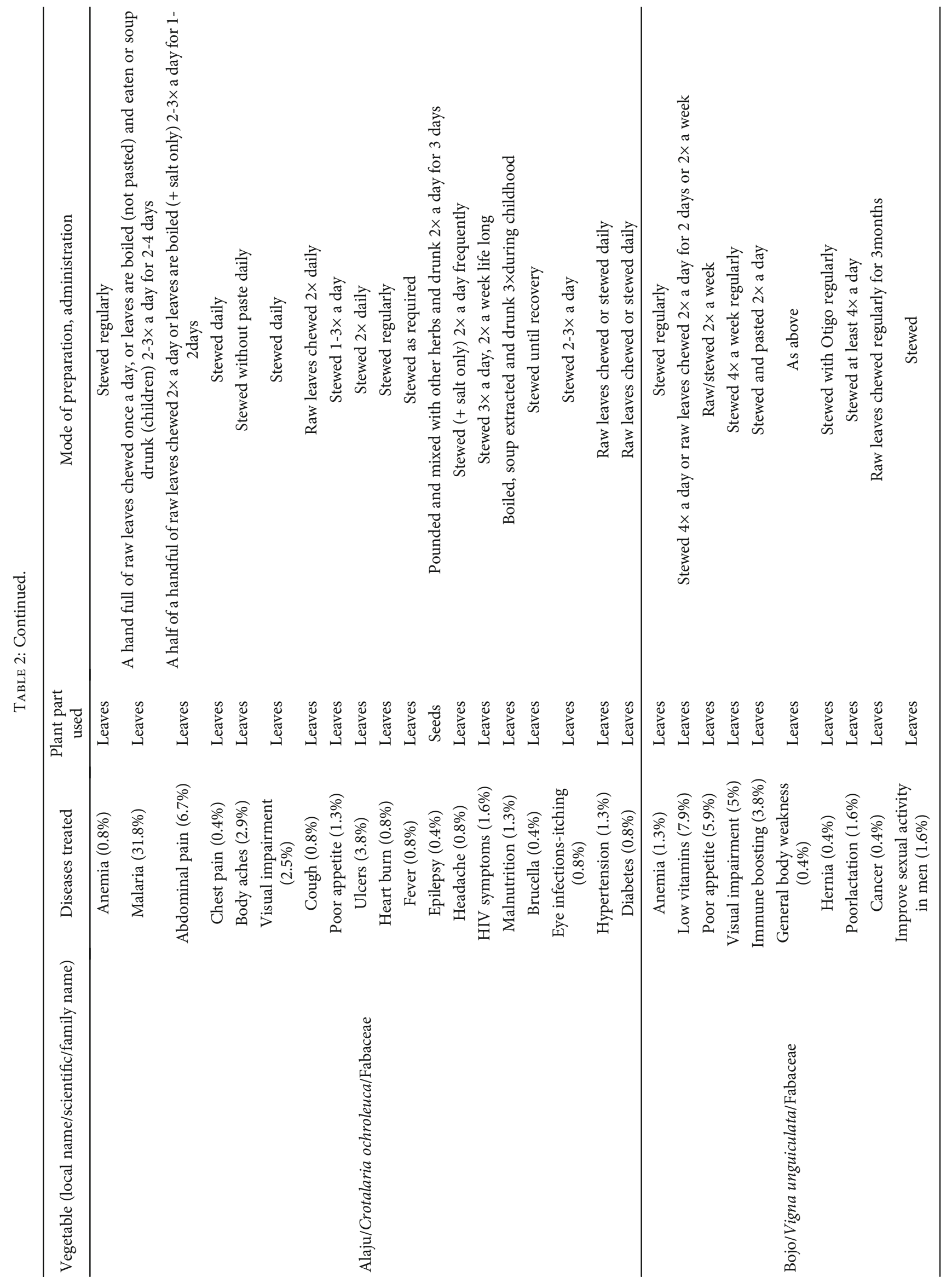




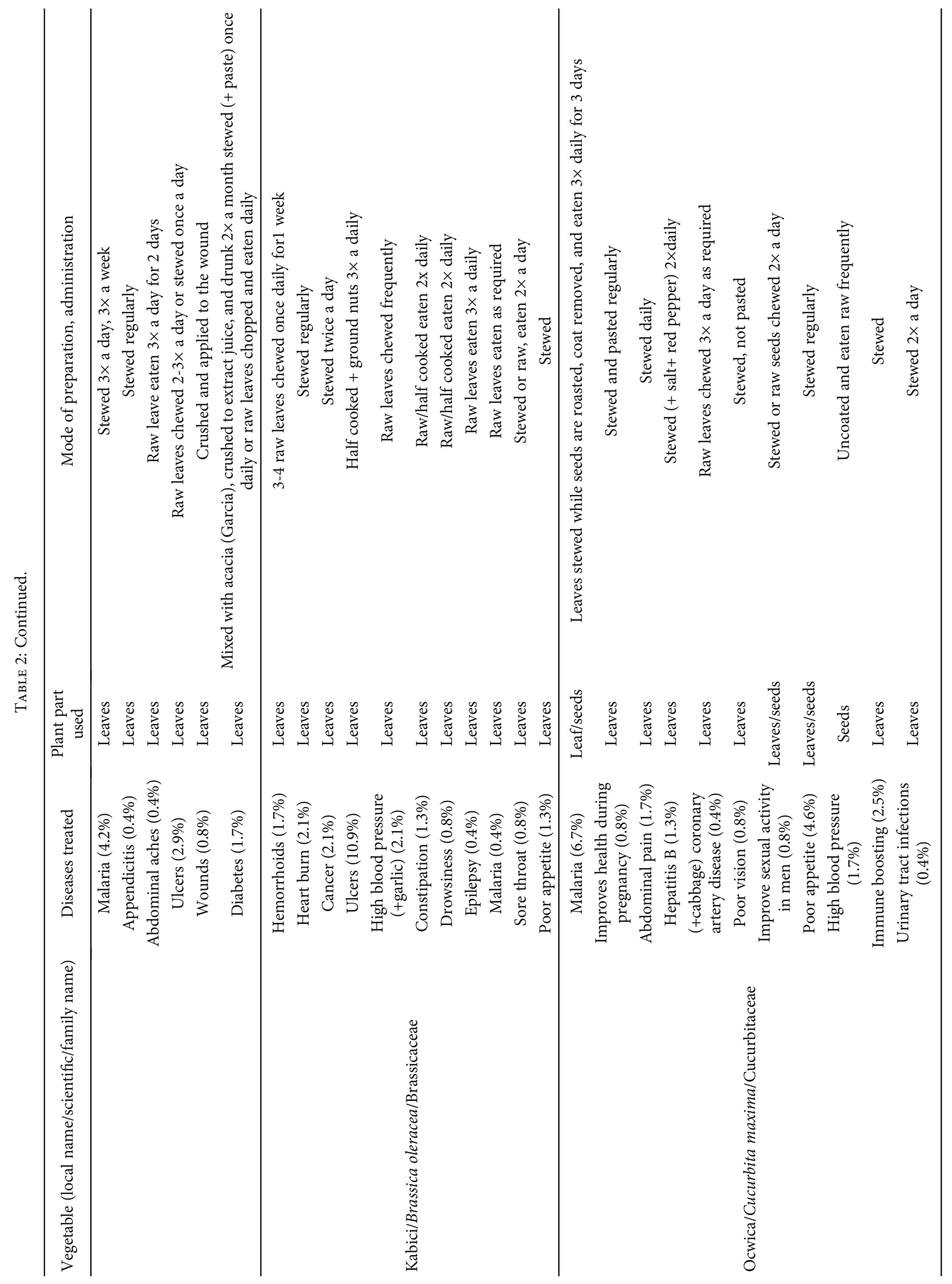




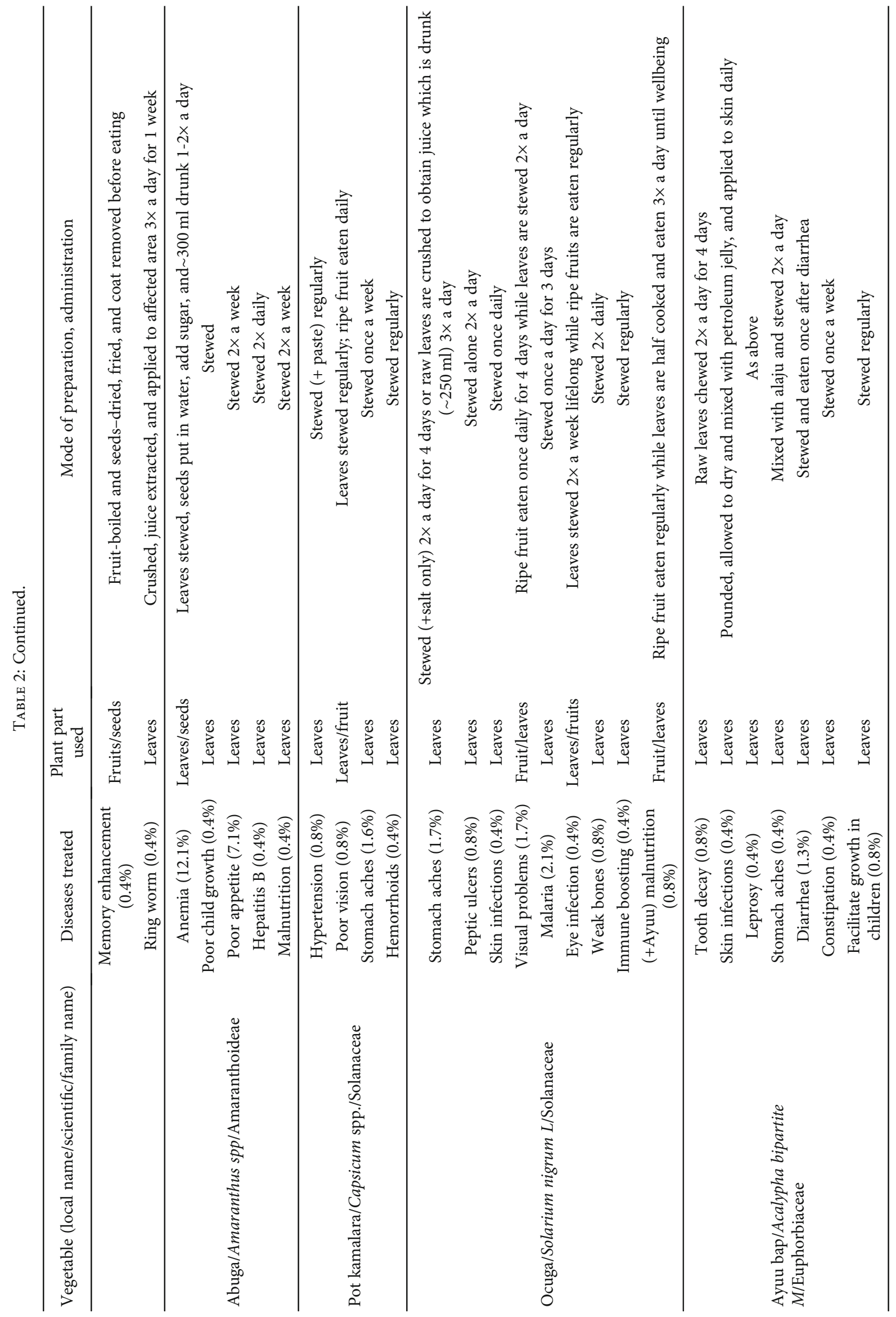




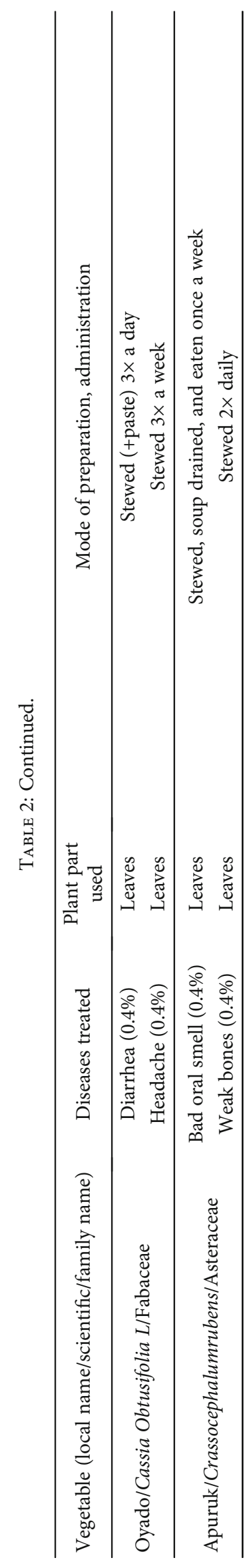




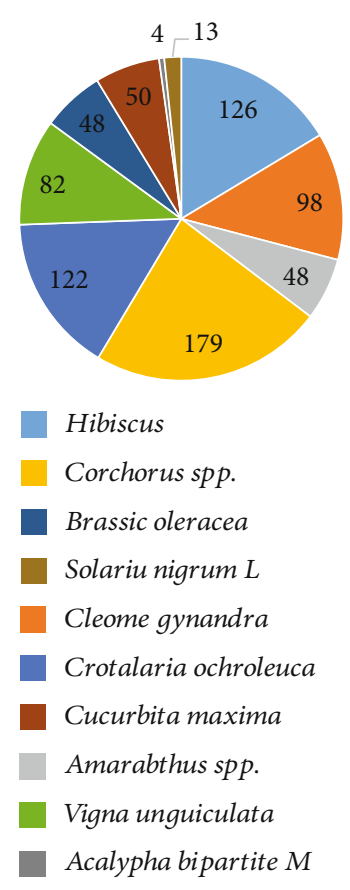

FIgURE 2: Vegetables most often used for medicinal purposes.

\section{Diseases Treated per Body Systems}

The traditional medicinal vegetables were used to treat diseases associated with diverse body systems. The disease treated was categorized into 10 categories as indicated in Table 5.

4.1. Source of Information. According to our findings, the study participants obtained information regarding traditional medicinal uses of the vegetables from (1) parents/guardians (69.5\%), (2) friends (23\%), (3) relatives (13.8\%), (4) Radio (15.9\%), and (5) neighbor (7.1\%). Other sources included experience (13.4\%), church $(0.8 \%)$, and market $(2.9 \%)$.

\section{Discussion}

Not only are traditional vegetables useful as food sources, they also provide a wide range of medicinal benefits. In our study, the participants were required to mention the vegetable, conditions treated, parts used, modes of preparation and administrations, and amount. 13 vegetables were reported to be used as traditional medicines (Table 2). The most mentioned were Corchorus spp. (77.4\%), Hibiscus spp. (59.8\%), Cleome gynandra (47.3\%), and Crotalaria ochroleuca (55.2\%). Corchorus spp. was reported the most effective in this study (Figure 3). They were used for treating conditions which ranged from gastrointestinal complications such as abdominal pains and oral thrush through reproductive abnormalities like difficulty birthing and male sexual complications to musculoskeletal disturbances such as joint pain and stiffness (Table 2). Meanwhile, the most commonly used parts included leaves which were stewed for the medicinal applications with no specific dosage for most of the conditions treated (Table 2). Some of the vegetables were administered a number of times per day while others per week or as required (Table 2). The most com- monly used and effective traditional medicinal vegetables were often cultivated especially in the backyard (Figure 4). Most of the participants obtained information regarding the medicinal uses of the traditional vegetables from their parents or guardians. Some of the traditional vegetables' medicinal applications documented in the current study relate to earlier findings [15] but a number of them do not. For instance, Hibiscus spp. was used for poor appetite, nausea, low saliva secretion, anemia, postpartum abdominal pain, poor lactation, oral thrush, skin swellings, wounds, ulcers, body swellings -esp. stomach swellings, poor vision, mouth sores with pus, cough, cold, flu, toothache, bone strength, painful eyes, and poisoning in the current study. These findings agree with those of Qi and Aziz $[34,35]$ in which the plant was found to treat sores and wounds, along with the findings of Mahadevan and Kamali $[36,37]$ where the plant was found to be useful as an antihelminth, antibacterial, and for cough. In addition, Hibiscus spp. is reported to be lactogenic $[38,39]$, in agreement with the current study. Cleome gynandra was used in the management of poor appetite, abdominal pain, scorpion bite, ringworm, difficult/prolonged labor, removal of retained placenta, postpartum bleeding, extreme headache, worm infestation, and eye/ear infections including removal of blood clots. These findings could be explained by the antimicrobial activity of the plant as reported by Ajayiyoeba and Amanirampa [40, 41] where the plant was reported to exhibit antibacterial and antifungal activity. In addition, Scippers and Kamatenesi [42, 43] found Cleome gynandra useful in migraine headaches, ear infections, and abdominal pains coupled to acceleration of labor and reduction of postpartum hemorrhage just as the current study findings. Corchorus spp. was used to treat joint pain and stiffness as well as weak joints. It was also found to strengthen bones and thus prevent fractures as well enhance fracture healing. This could be attributed to the fact that the plant is rich in calcium as reported by Idris [44] which favors mineralization thus strengthening the bones or due to the antioxidant activity of the plant which activates differentiation of osteoblasts, enhances bone mineralization, and reduces osteoclast activity $[45,46]$. In Zimbabwe, Corchorus spp. is used for backaches [47] which is in agreement with the current study findings since the study participants reported using the plant for body aches. On the contrary, Corchorus spp is used in Benin for cardiac insufficiency, fever, malaria, female fertility, ulcerations, and gastrointestinal problems [48]. The plant was also reported to be useful as an antiulcer, laxative/purgative in the current study probably due to its richness in fiber [49], and its gastroprotective effects [50, 51]. Crotalaria ochroleuca was found by the current study to treat malaria, abdominal pain, ulcers, epilepsy, chest pain, body aches, hypertension, and diabetes (Table 2). These findings agree with those of Anywar and Ashuraduzzaman [31, 52] where the plant was found to treat malaria and relieve bronchospasms which could be responsible for the chest pain in the current study. According to a study conducted in Nigeria, the plant was found to have antibacterial and antifungal activity [53]. This could explain its use for abdominal pains, Brucella, cough, and fever in the current study. Vigna unguiculata was reported to alleviate poor appetite, abdominal pains, ulcers, and visual impairment in the current study. The 


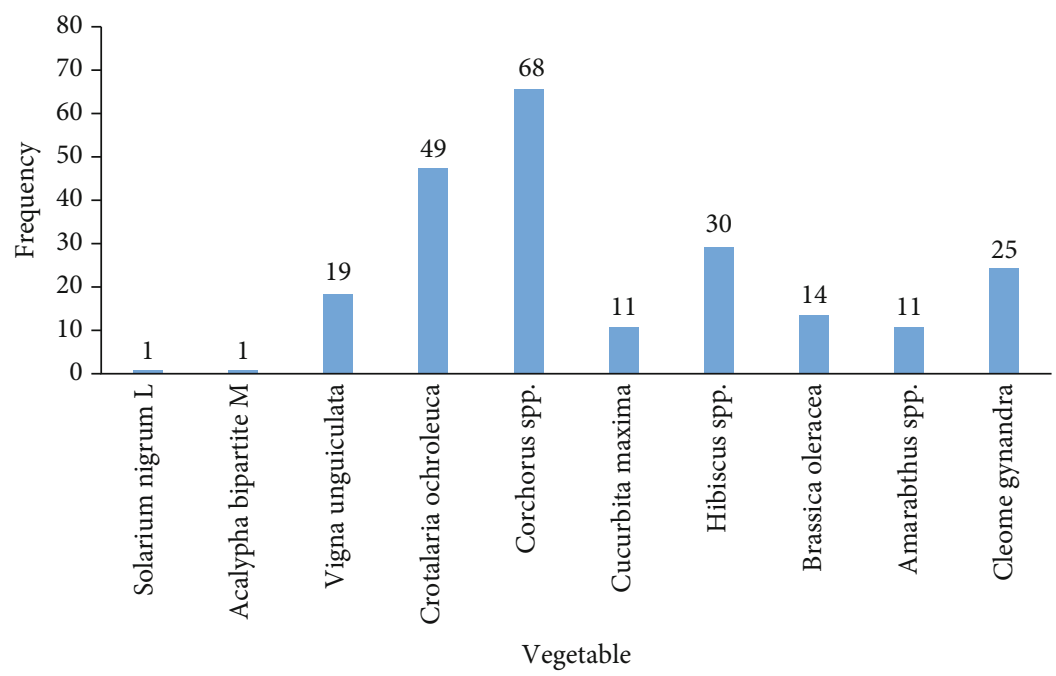

FIgure 3: The most effective medicinal vegetables in Northern Uganda.

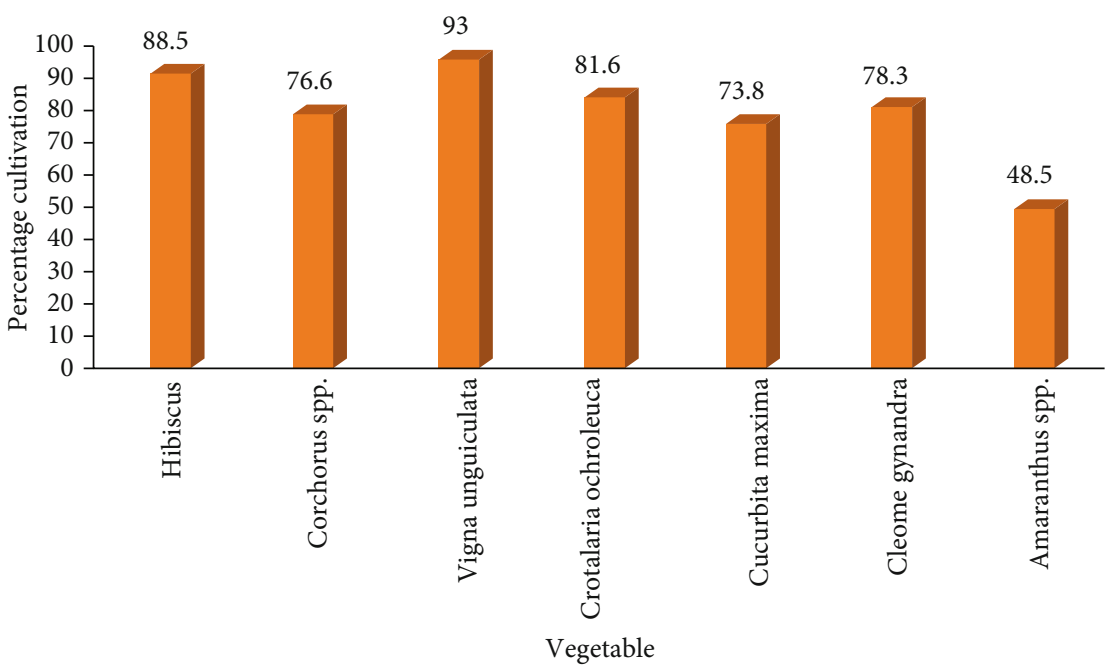

FIgURE 4: Cultivation of medicinal vegetables in Northern Uganda.

findings of Kritzinger et al. and Sayeed et al indicated that the plant had antimicrobial activity [54] [55]. These findings support the current use of the plant for abdominal pains. In addition, this is a green leafy vegetable rich in vitamin A which is well known for improving sight [56]. Brassica oleracea was used for ulcers, hypertension, malaria, constipation, epilepsy, and sore throat in the current study. This could be partly explained by the fact that the plant is bioactive [57] and fiber rich [58]. Cucurbita maxima was found to improve male sexual activity and fetal health, enhance wound healing, enhance memory, and treat hepatitis B and coronary artery disease in the present study. On the contrary, a study by Dubey showed that the plant was used as a remedy for tape worms, as a sedative, a tonic, a diuretic, has anticancer, antidiabetic, and hepatoprotective activity [59]. The plant was found by Solomon et al. to have antimicrobial activity [60] justifying the wound healing effect in the current study. Amaranthus spp. has been reported to boost blood levels [61] while Crota- laria ochroleuca as an antimalarial agent [31]. These findings coincide with the current reports. The most frequent plant part used in the current study was the leaves. This was in agreement with other related studies $[13,62,63]$. The informant consensus factors (ICF) were calculated for the most commonly used traditional medicinal vegetables to ascertain the consistency of informants' ethnopharmacological knowledge (table 3 ). Usage of a variety of vegetables for a particular disease greatly reduced the ICF while for conditions where only a few vegetables were used, the resultant ICF was higher. High ICF values indicated wide usage (informant agreement) of a vegetable for a particular disease and hence calling for further pharmacological and phytochemical investigations. The vegetable and conditions with the highest ICF were Corchorus spp. for joint stiffness, joint weakness, and pain $(\mathrm{ICF}=1)$; Hibiscus spp. for poor lactation; Crotalaria ochroleuca for malaria and body aches (ICF > 0.83); and Cleome gynandra for ringworm and abdominal pain (ICF >0.75). 
TABLE 3: ICF values for the diseases commonly treated by the traditional medicinal vegetables in Northern Uganda.

\begin{tabular}{|c|c|c|c|c|}
\hline Vegetable & Condition & $\begin{array}{l}\text { No of participants report on condition } \\
\qquad(n)\end{array}$ & $\begin{array}{l}\text { Total No. of species for condition } \\
\text { (nt) }\end{array}$ & $\mathrm{ICF}=(n-\mathrm{nt}) /(n-1)$ \\
\hline \multirow{7}{*}{ Corchorus spp. } & Joint stiffness & 67 & 1 & 1 \\
\hline & Constipation & 14 & 4 & 0.77 \\
\hline & Poor appetite & 26 & 9 & 0.68 \\
\hline & Purgation & 6 & 1 & 1 \\
\hline & Joint pain & 14 & 2 & 0.92 \\
\hline & Joint weakness & 22 & 1 & 1 \\
\hline & Weak bones & 7 & 2 & 0.83 \\
\hline \multirow{4}{*}{ Hibiscus spp. } & Poor appetite & 74 & 10 & 0.88 \\
\hline & Cough & 5 & 2 & 0.75 \\
\hline & Poor lactation & 26 & 1 & 1 \\
\hline & Ulcers & 5 & 6 & -0.25 \\
\hline \multirow{6}{*}{$\begin{array}{l}\text { Crotalaria } \\
\text { ochroleuca }\end{array}$} & Malaria & 76 & 8 & 0.91 \\
\hline & Body aches & 7 & 2 & 0.83 \\
\hline & Poorhealth & 5 & 2 & 0.75 \\
\hline & Poor vision & 6 & 9 & -0.6 \\
\hline & Abdominal pain & 16 & 8 & 0.53 \\
\hline & Ulcers & 9 & 6 & 0.38 \\
\hline \multirow{6}{*}{ Cleome gynandra } & Malaria & 12 & 8 & 0.36 \\
\hline & Poor vision & 10 & 9 & 0.1 \\
\hline & Headache & 8 & 4 & 0.57 \\
\hline & Poor appetite & 11 & 10 & 0.1 \\
\hline & Ring worm & 21 & 2 & 0.95 \\
\hline & Abdominal pain & 34 & 8 & 0.79 \\
\hline \multirow{5}{*}{ Vigna unguiculata } & Poor appetite & 14 & 10 & 0.31 \\
\hline & Poor vision & 12 & 9 & 0.27 \\
\hline & Immune boosting & 9 & 4 & 0.63 \\
\hline & Malaria & 10 & 8 & 0.22 \\
\hline & Ulcers & 7 & 6 & 0.17 \\
\hline \multirow{3}{*}{ Cucurbita maxima } & Malaria & 16 & 8 & 0.53 \\
\hline & Poor appetite & 11 & 10 & 0.1 \\
\hline & Poor health & 6 & 3 & 0.6 \\
\hline \multirow{2}{*}{ Amaranthus spp. } & Anemia & 29 & 7 & 0.79 \\
\hline & Poor appetite & 7 & 10 & -0.5 \\
\hline \multirow{4}{*}{ Brassica oleracea } & Heart burn & 5 & 3 & 0.5 \\
\hline & Ulcers & 26 & 6 & 0.8 \\
\hline & $\begin{array}{l}\text { High blood } \\
\text { pressure }\end{array}$ & 5 & 6 & 0.25 \\
\hline & Cancer & 5 & 1 & 1 \\
\hline
\end{tabular}

The high ICF for Corchorus spp. contradicts findings of other studies within and without the region [64-68]. Thus, the uses in the current study (joint pain/stiffness) differ from the uses elsewhere (muscle spasms, wounds). The ICF findings for Hibiscus spp. and Crotalaria ochroleuca as well as for Cleome gynandra agree with other studies in the region [31, 39-41]. On the other hand, the fidelity levels (FL) for vegetables with ICF values $\geq 0.5$ were calculated to quantify their importance to treat a disease (Table 4). The FL values were the highest for Amaranthus spp. (Anemia, 60.4\%) and Crotalaria ochroleuca (malaria, 57.6\%). This is supported by previous findings in the country $[31,61]$. However, the current findings for Hibiscus spp. (poor appetite, 51.8\%) and Corchorus spp. (joint pain and stiffness, $43.8 \%$ ) contradict previous studies in other regions $[39,68]$.High FL values indicate a high cultural significance for the vegetable. In a bid to strengthen conservation, 
TABLE 4: Fidelity levels of the most common medicinal vegetables.

\begin{tabular}{|c|c|c|c|c|}
\hline Vegetable & Condition & $\begin{array}{l}\text { No of participants report on condition } \\
\qquad\left(I_{p}\right)\end{array}$ & $\begin{array}{l}\text { Total No. of reports for any use } \\
\qquad\left(I_{u}\right)\end{array}$ & $\mathrm{FL}=\left(I_{p} / I_{u}\right) \times 100$ \\
\hline \multirow{5}{*}{ Corchorus spp. } & $\begin{array}{l}\text { Joint pain and } \\
\text { stiffness }\end{array}$ & 81 & 185 & 43.78 \\
\hline & Constipation & 14 & 185 & 7.57 \\
\hline & Poor appetite & 26 & 185 & 14.05 \\
\hline & Joint weakness & 22 & 185 & 11.89 \\
\hline & Weak bones & 7 & 185 & 3.78 \\
\hline \multirow{3}{*}{ Hibiscus spp. } & Poor appetite & 74 & 143 & 51.75 \\
\hline & Cough & 5 & 143 & 3.50 \\
\hline & Poor lactation & 26 & 143 & 18.18 \\
\hline \multirow{7}{*}{$\begin{array}{l}\text { Crotalaria } \\
\text { ochroleuca }\end{array}$} & Malaria & 76 & 132 & 57.58 \\
\hline & Body aches & 7 & 132 & 5.30 \\
\hline & Poor health & 5 & 132 & 3.79 \\
\hline & Abdominal pain & 16 & 132 & 12.12 \\
\hline & Headache & 8 & 113 & 7.08 \\
\hline & Ring worm & 21 & 113 & 18.58 \\
\hline & Abdominal pain & 34 & 113 & 30.09 \\
\hline Vigna unguiculata & Immune boosting & 9 & 82 & 10.98 \\
\hline \multirow{2}{*}{ Cucurbita maxima } & Malaria & 16 & 56 & 28.57 \\
\hline & Poor health & 6 & 56 & 10.7 \\
\hline Amaranthus spp. & Anemia & 29 & 48 & 60.42 \\
\hline \multirow{4}{*}{ Brassica oleracea } & Hemorrhoids & 4 & 56 & 7.14 \\
\hline & Heart burn & 5 & 56 & 8.9 \\
\hline & Ulcers & 26 & 56 & 46.43 \\
\hline & Cancer & 5 & 56 & 8.93 \\
\hline
\end{tabular}

TABLE 5: Diseases treated by traditional vegetables in Northern Uganda per body system.

\begin{tabular}{|c|c|}
\hline System & Diseases treated \\
\hline Digestive system & $\begin{array}{l}\text { Poor appetite, nausea, low saliva production, oral thrush, peptic ulcers, abdominal pain, bloating, flatulence, purgation, } \\
\text { heart burn, diarrhea, bad oral smell, constipation, hemorrhoids, sore throat, hernia }\end{array}$ \\
\hline $\begin{array}{l}\text { Reproductive } \\
\text { system }\end{array}$ & $\begin{array}{c}\text { Postpartum abdominal pain, poor lactation, sexual difficulties, prolonged labor, placenta removal, pregnancy, } \\
\text { miscarriages }\end{array}$ \\
\hline Endocrine system & Diabetes, goiter \\
\hline $\begin{array}{l}\text { Musculoskeletal } \\
\text { system }\end{array}$ & Waist and backaches, joint pain and stiffness, joint weakness, bone fractures, muscle rigidity, tooth decay \\
\hline Respiratory system & Cough, flu/cold \\
\hline Renal system & Urinary tract infections \\
\hline $\begin{array}{l}\text { Cardiovascular } \\
\text { system }\end{array}$ & Hypertension, anemia, headache, coronary artery disease, blood vessel engorgement \\
\hline Nervous system & Poor vision, mental illnesses, memory enhancement, drowsiness, epilepsy \\
\hline $\begin{array}{l}\text { Integumentary } \\
\text { system }\end{array}$ & Skin rashes and infections, leprosy, ring worm, scabies, wounds \\
\hline Others & $\begin{array}{l}\text { Malnutrition, growth retardation, eye/ear infections, immune boosting, malaria, helminth infestation, HIV symptoms, } \\
\text { hepatitis B, wound healing, hang over, cancer, Brucella, fever, sickle cell disease, poisoning, rough voice, scorpion bite }\end{array}$ \\
\hline
\end{tabular}


several ethnobotanical studies are being conducted in the country $[64,65,69]$. However, these studies major on documentation of medicinal plants and their uses rather than engaging the communities to actively participate in the conservation process at family levels. As such, community sensitization with these studies' findings is highly called for if these medicinal plants are to be conserved and preserved for the generations to come.

\section{Conclusion}

Northern Uganda has numerous traditional vegetables with medicinal benefits. Diseases treated range from gastrointestinal to reproductive through musculoskeletal abnormalities. The community obtains vegetable leaves from the backyard and stews them regularly for the medicinal purposes with no specific dosage. Therefore, we recommend studies to verify in laboratory models the efficacy of these vegetables and standardize the dosages.

\section{Data Availability}

The datasets generated and/or analyzed during the current study may be obtained from the corresponding author upon reasonable request.

\section{Ethical Approval}

The study was approved by the Research Ethics Committee of Mbarara University of Science and Technology and the Uganda National Council for Science and Technology (UNCST-HS2589). In addition, informed consent was obtained from the study participants who signed a consent form following explanation of the study aims and procedures.

\section{Disclosure}

Data was collected for academic purposes, as a requirement for the award of the degree of Doctor of Philosophy of Mbarara University of Science and Technology, Mbarara, Uganda.

\section{Conflicts of Interest}

The authors declare that there are no competing interests.

\section{Authors' Contributions}

NR performed the conception of idea, methods, data collection, and first manuscript draft. SBA and MKA performed the research design, data collection, and manuscript review. CDS and FB performed the research design and manuscript review. JOK and PA performed the general oversight and manuscript review. All authors read and approved the final manuscript.

\section{Acknowledgments}

The authors thank the leaders and community of the Lango subregion, Northern Uganda, and also the data collection team: Mr. Opii Didan Jacob, Mr. Opio Ojok Innocent, Mr. Oleke Felix, Mr. Beja Humphrey, and Mr. Odong Alex.

\section{References}

[1] C. Veeresham, "Natural products derived from plants as a source of drugs," Journal of advanced pharmaceutical technology \& research, vol. 3, no. 4, article 104709, pp. 200-201, 2012.

[2] M. Wolde-Mariam, A. Gari, and R. Yarlagadda, "Knowledge, attitude, practice, and management of traditional medicine among people of Burka Jato Kebele, West Ethiopia," Research Journal of Pharmaceutical, Biological and Chemical Sciences, vol. 7, no. 2, article 148782, pp. 136-144, 2015.

[3] J. R. Tabuti, "Herbal medicines used in the treatment of malaria in Budiope county, Uganda," Journal of ethnopharmacology, vol. 116, no. 1, pp. 33-42, 2008.

[4] B. Rasool Hassan, "Medicinal plants (importance and uses)," Pharmaceutica Analytica Acta, vol. 3, article e139, p. 10, 2012.

[5] M. Potroz and N.-J. Cho, "Natural products for the treatment of trachoma and chlamydia trachomatis," Molecules, vol. 20, no. 3, pp. 4180-4203, 2015.

[6] C. Chandekar and M. Madhugiri, "Antimicrobial potential of leaves of Psidium guajava," The Bioscan, vol. 6, no. 4, pp. 557-561, 2011.

[7] D. Quiroz, M. Sosef, and T. Van Andel, "Why ritual plant use has ethnopharmacological relevance," Journal of Ethnopharmacology, vol. 188, pp. 48-56, 2016.

[8] E. van der Watt and J. C. Pretorius, "Purification and identification of active antibacterial components in Carpobrotus eduli L.," Journal of Ethnopharmacology, vol. 76, no. 1, pp. 87-91, 2001.

[9] M. Sharif and G. R. Banik, "Status and utilization of medicinal plants in Rangamati of Bangladesh," Research Journal of Agriculture and Biological Sciences, vol. 2, no. 6, pp. 268-273, 2006.

[10] K. Abascal and E. Yarnell, "Botanical galactagogues," Alternative and Complementary Therapies, vol. 14, no. 6, pp. 288-294, 2008.

[11] World Health Organization, "WHO Model List of Essential Medicines: 17th List, March 2011," 2011.

[12] D. S. Fabricant and N. R. Farnsworth, "The value of plants used in traditional medicine for drug discovery," Environmental health perspectives, vol. 109, supplement 1, pp. 69-75, 2001.

[13] V. S. Kamble and V. D. Jadhav, "Traditional leafy vegetables: a future herbal medicine," International Journal of Agricultural and Food Science, vol. 3, no. 2, pp. 56-58, 2013.

[14] K. Parikh, "Medicinal importance of some common indian vegetables part I," Ancient science of life, vol. 4, no. 4, pp. 232-237, 1985.

[15] E. B. Rubaihayo, "Conservation and use of traditional vegetables in Uganda," Promoting the Conservation and Use of Underutilized and Neglected Crops (IPGRI), vol. 16, 1997.

[16] E. Musinguzi, J. K. Kikafunda, and B. Kiremire, "Utilization of indigenous food plants in Uganda: a case study of southwestern Uganda," African Journal of Food, Agriculture, Nutrition and Development, vol. 6, no. 2, 2011.

[17] E. Rubaihayo, "Uganda-the Ccontribution of indigenous vegetables to household food security," 2002.

[18] K. J. Child and N. Guidelines, Produced by Mwanamugimu Nutrition Services, Ministry of Health and the Department of Home Economics, Ministry of Agriculture, Uganda, 1984. 
[19] S. Ignacimuthu, M. Ayyanar, and S. Sivaraman K, "Ethnobotanical investigations among tribes in Madurai district of Tamil Nadu (India)," Journal of Ethnobiology and Ethnomedicine, vol. 2, no. 1, p. 25, 2006.

[20] A. K. Gautam, M. K. Bhatia, and R. Bhadauria, "Diversity and Usage Custom of Plants of Western Himachal Pradesh, IndiaPart I," Journal of Phytology, vol. 3, no. 2, pp. 24-36, 2011.

[21] Statistics UBo, The National Population and Housing Census 2014 - Area Specific Profile Series, Uganda Bureau of Statistics, Kampala, Uganda, 2017.

[22] M. Bamberger, Integrating Quantitative and Qualitative Research in Development Projects: Lessons from the Field, The World Bank, 2000.

[23] J. Brannen, "Mixing methods: the entry of qualitative and quantitative approaches into the research process," International journal of social research methodology., vol. 8, no. 3, pp. 173-184, 2005.

[24] H. Taherdoost, "Sampling methods in research methodology; how to choose a sampling technique for research," in How to Choose a Sampling Technique for Research (April 10, 2016), 2016.

[25] S. Methodology, "Sampling methods and sample size calculation for SMART methodology," 2012.

[26] L. S. Whiting, "Semi-structured interviews: guidance for novice researchers," Nursing standard, vol. 22, no. 23, pp. 35-40, 2008.

[27] M. J. McIntosh and J. M. Morse, "Situating and constructing diversity in semi-structured interviews," Global qualitative nursing research, vol. 2, 2015.

[28] M. K. David and L. L. Ching, "Using the key informants interviews (KIIs) technique: a social sciences study with Malaysian and Pakistani," 2013.

[29] E. Van Teijlingen and V. Hundley, "The importance of pilot studies," Social research update, vol. 35, no. 4, pp. 49-59, 2010.

[30] International Society of Ethnobiology, "International society of ethnobiology code of ethics (with 2008 additions)," 2006.

[31] G. Anywar, C. I. van't Klooster, R. Byamukama et al., "Medicinal plants used in the treatment and prevention of malaria in Cegere sub-County, Northern Uganda," Ethnobotany research \& applications, vol. 14, pp. 505-516, 2016.

[32] V. Reyes-García, N. Marti, T. McDade, S. Tanner, and V. Vadez, "Concepts and methods in studies measuring individual ethnobotanical knowledge," Journal of Ethnobiology, vol. 27, no. 2, pp. 182-203, 2007.

[33] G. J. Martin, Ethnobotany: a methods manual, Springer, 2014.

[34] Y. Qi, K. L. Chin, F. Malekian, M. Berhane, and J. Gager, "Biological characteristics, nutritional and medicinal value of roselle, Hibiscus sabdariffa," Circular-urban forestry natural resources and environment, vol. 604, pp. 1-2, 2005.

[35] E. E. Aziz, N. Gad, and N. Badran, "Effect of cobalt and nickel on plant growth, yield and flavonoids content of Hibiscus sabdariffa L," Australian Journal of Basic and Applied Sciences, vol. 1, no. 2, pp. 73-78, 2007.

[36] M. N. Shivali and P. Kamboj, "Hibiscus sabdariffa linn-an overview," Natural Product Radiance, vol. 8, no. 1, pp. 77$83,2009$.

[37] H. Kamali and M. F. Mohammed, "Antibacterial activity of Hibiscus sabdariffa, Acacia seyal var. seyal and Sphaeranthus suaveolens var. suaveolens against upper respiratory tract pathogens," Sudan Journal of Medical Sciences, vol. 1, no. 2, pp. 121-126, 2006.
[38] I. Bako, M. Mabrouk, M. Abubakar, and A. Mohammed, "Lactogenic study of the ethyl-acetate fraction of Hibiscus sabdariffa linn seed on pituitary prolactin level of lactating albino rats," International Journal of Applied Research in Natural Products, vol. 6, no. 2, pp. 30-37, 2013.

[39] M. Okasha, M. Abubakar, and I. Bako, "Study of the effect of aqueous Hibiscus sabdariffa Linn seed extract on serum prolactin level of lactating female albino rats," European Journal of Scientific Research, vol. 22, no. 4, pp. 575-583, 2008.

[40] E. Ajaiyeoba, "Phytochemical and antimicrobial studies of Gynandropsis gynandra and Buchholzia coriaceae extracts," African Journal of Biomedical Research, vol. 3, no. 3, pp. 161-165, 2000.

[41] L. Imanirampa and P. E. Alele, "Antifungal activity of Cleome gynandra L. aerial parts for topical treatment of Tinea capitis: an in vitro evaluation," BMC complementary and alternative medicine, vol. 16, no. 1, p. 194, 2016.

[42] R. R. Schippers, African Indigenous Vegetables: An Overview of the Cultivated Species, Natural Resources International Limited, 2002.

[43] M. Kamatenesi-Mugisha and H. Oryem-Origa, "Medicinal plants used to induce labour during childbirth in western Uganda," Journal of Ethnopharmacology, vol. 109, no. 1, pp. 1-9, 2007.

[44] S. Idirs, J. Yisa, and M. Ndamitso, "Nutritional composition of Corchorus olitorius leaves," Animal Production Research Advances, vol. 5, no. 2, 2010.

[45] V. Domazetovic, G. Marcucci, T. Iantomasi, M. L. Brandi, and M. T. Vincenzini, "Oxidative stress in bone remodeling: role of antioxidants," Clinical Cases in Mineral and Bone Metabolism, vol. 14, no. 2, pp. 209-216, 2017.

[46] B. Andabati and J. Muyonga, "Phenolic content and antioxidant activity of selected Ugandan traditional medicinal foods," African Journal of Food Science, vol. 8, no. 8, pp. 427-434, 2014.

[47] A. Maroyi, "Traditional use of medicinal plants in southCentral Zimbabwe: review and perspectives," Journal of ethnobiology and ethnomedicine, vol. 9, no. 1, p. 31, 2013.

[48] H. O. Adebo, L. E. Ahoton, F. J. Quenum, H. Adoukonou-Sagbadja, D. O. Bello, and C. A. Chrysostome, "Ethnobotanical knowledge of jute (Corchorus olitorius L.) in Benin," Journal of Medicinal Plants, vol. 26, no. 1, pp. 1-11, 2018.

[49] J. Ndlovu and A. Afolayan, "Nutritional analysis of the South African wild Vegetable Corchorus olitorius L," Asian Journal of Plant Sciences, vol. 7, no. 6, pp. 615-618, 2008.

[50] R. al Batran, F. al-Bayaty, M. Ameen Abdulla et al., "Gastroprotective effects of Corchorus olitorius leaf extract against ethanol- induced gastric mucosal hemorrhagic lesions in rats," Journal of Gastroenterology and Hepatology, vol. 28, no. 8, pp. 1321-1329, 2013.

[51] M. Ashraduzzaman, M. Alam, S. Khatun, and N. Absar, "Antimicrobial activity of Vigna unguiculata L. Walp seed oil," International Journal of Biotechnology for Wellness Industries, vol. 5, no. 3, pp. 70-75, 2016.

[52] A. Ezike, P. Akah, and C. Okoli, "Bronchospasmolytic activity of the extract and fractions of Asystasia gangetica l eaves," 2008.

[53] A. Hamid, O. Aiyelaagbe, R. Ahmed, L. Usman, and S. Adebayo, "Preliminary phytochemistry, antibacterial and antifungal properties of extracts of Asystasia gangetica Linn T. Anderson grown in Nigeria," Journal of advanced applied scientific research, vol. 2, no. 3, pp. 219-226, 2011. 
[54] Q. Kritzinger, N. Lall, T. Aveling, and B.-E. van Wyk, "Antimicrobial activity of cowpea (Vigna unguiculata) leaf extracts," South African Journal of Botany, vol. 71, no. 1, pp. 45-48, 2005.

[55] V. K. I. Sayeed, S. Satish, A. Kumar, and K. Hegde, "Pharmacological Activities of Vigna Unguiculata (L) Walp: A review," International Journal of Pharma and Chemical Research, vol. 3, no. 1, pp. 44-49.

[56] R. Oruch and I. F. Pryme, “The biological significance of vitamin a in humans: a review of nutritional aspects and clinical considerations," Science Jet, vol. 1, p. 19, 2012.

[57] S. Paul, T. B. Emran, D. Saha, and S. Z. Hosen, "Phytochemical and antimicrobial activity of the plant extracts of Brassica oleracea against selected microbes," Asian Journal of Pharmacy and Medical Science, vol. 2, p. 2, 2012.

[58] C. Ravikumar, "Therapeutic potential of Brassica oleracea (broccoli)-a review," International Journal of Drug Development and Research, vol. 7, no. 2, pp. 009-010, 2015.

[59] S. D. Dubey and S. Dubey, "Overview on Cucurbita maxima," International Journal of Phytopharmacy, vol. 2, no. 3, pp. 6871, 2012.

[60] N. Muruganantham, S. Solomon, and M. Senthamilselvi, "Antimicrobial activity of Cucurbita maxima flowers (pumpkin)," Journal of Pharmacognosy and Phytochemistry, vol. 5, no. 1, p. 15, 2016.

[61] N. K. Maurya and P. Arya, "Amaranthus grain nutritional benefits: a review," Journal of Pharmacognosy and Phytochemistry, vol. 7, no. 2, pp. 2258-2262, 2018.

[62] G. L. Tilford, Edible and medicinal plants of the West, Mountain Press Publishing, 1997.

[63] T. K. Lim, Edible medicinal and non-medicinal plants, Springer, 2012.

[64] L. Ssozi, B. Kabiito, A. Byaruhanga, and W. Kanata, "Documenting Baganda ethno-medicine: a step towards preservation and conservation," Journal of Applied and Advanced Research, vol. 1, no. 2, pp. 15-22, 2016.

[65] J. R. Tabuti, C. B. Kukunda, D. Kaweesi, and O. M. Kasilo, "Herbal medicine use in the districts of Nakapiripirit, Pallisa, Kanungu, and Mukono in Uganda," Journal of ethnobiology and ethnomedicine, vol. 8, no. 1, p. 35, 2012.

[66] P. Tugume, E. K. Kakudidi, M. Buyinza et al., "Ethnobotanical survey of medicinal plant species used by communities around Mabira Central Forest Reserve, Uganda," Journal of ethnobiology and ethnomedicine, vol. 12, no. 1, p. 5, 2016.

[67] J. Okello and P. Ssegawa, "Medicinal plants used by communities of Ngai subcounty, Apac District, northern Uganda," African Journal of Ecology, vol. 45, no. s1, pp. 76-83, 2007.

[68] M. M. Islam, "Biochemistry, medicinal and food values of jute (Corchorus capsularis L. and C. olitorius L.) leaf: a review," International Journal of Enhanced Research In Science Technology \& Engineering, vol. 2, no. 11, pp. 135-144, 2013.

[69] J. R. S. Tabuti, C. B. Kukunda, and P. J. Waako, "Medicinal plants used by traditional medicine practitioners in the treatment of tuberculosis and related ailments in Uganda," Journal of Ethnopharmacology, vol. 127, no. 1, pp. 130-136, 2010. 